УДК $811.16: 81.27: 81.37(038)$

DOI https://doi.org/10.26661/2414-1135-2021-84-7

\title{
ЛЕКСИКОГРАФУВАННЯ СЛІВ ГЕЙМЕРСЬКОГО ЖАРГОНУ РОСІЙСЬКОЇ ТА ПОЛЬСЬКОЇ МОВ НА ПРИКЛАДІ ГРИ ФОТА 2
}

\author{
Горлач В. В. \\ кандидат педагогічних наук, \\ дочент кафедри слов'янської філології \\ Запорізький національний університет \\ вул. Жуковського, 66, Запоріжжя, Україна \\ orcid.org/0000-0001-6719-5605 \\ val_g161@ukr.net \\ Доня В. А. \\ студентка магістратури \\ кафедри слов'янської філології \\ Запорізький національний університет \\ вул. Жуковського, 66, Запоріжжя, Україна \\ orcid.org/0000-0003-1368-562X \\ lera.donya228@gmail.com
}

\begin{abstract}
Ключові слова: словникова стаття, семантизація, компаративний аналіз, онлайн-гра, макро- та мікроструктура словника.
\end{abstract}

В епоху глобалізації, тотальної комп'ютеризації та інформатизації всесвітня мережа стає невіддільною частиною життя людини. Одним із популярних віртуальних місць спілкування, окрім соціальних мереж, $\epsilon$ онлайн-ігри, в яких існує своя специфічна лексика - геймерський жаргон. Попри те, що сучасна людина проводить в Інтернеті більшу частину свого дня, та онлайн-ігри, особливо серед молоді, щороку стають більш популярними, досліджень геймерського жаргону, зокрема лексикографічних робіт щодо зазначеної лексики, не так багато. Дослідження присвячене спробі описати та охарактеризувати структуру польсько-російського словника геймерського жаргону. В статті надано дефініцію поняття жаргон та виділені особливості власне геймерського жаргону, який слід відрізняти від комп'ютерного; описуються структурні елементи, за якими створено словник, та перелічені одиниці, з яких складається його макро- та мікроструктура. В запропонованому лексикографічному описі геймерського жаргону в російській і польській мовах враховуються фонетичні, графічні, граматичні, словотвірні особливості кожної 3 мов і здійснюється компаративний аналіз їх диференціальних ознак. Виділені специфічні ознаки ілюструються прикладами, які якнайбільше розкривають та аргументують сутність висловлювань. Словник базується на основних принципах лексикографування: наступництво лексикографічних творів, значна роль суб'єктивного фактора, зумовленість жорстким прагматизмом, нормативність у відборі й подачі лексичного матеріалу, теоретична й практична багатоплановість лексикографічних творів. Результати цього дослідження дали змогу порівняти систему геймерського жаргону у російській та польській мовах, виділити в них спільні та відмінні ознаки, підкреслити особливості кожної з мов щодо використання досліджуваних лексичних одиниць. 


\title{
LEXICOGRAPHY OF WORDS OF GAMING JARGON IN RUSSIAN AND POLISH LANGUAGES ON THE EXAMPLE OF THE GAME DOTA 2
}

\author{
Gorlach V. V. \\ Candidate of Pedagogical Sciences, \\ Associate Professor at the Department of Slavic Philology \\ Zaporizhzhia National University \\ Zhukovskoho str., 66, Zaporizhzhia, Ukraine \\ orcid.org/0000-0001-6719-5605 \\ val_g161@ukr.net \\ Donia V. A. \\ Master Student at the Department of Slavic Philology \\ Zaporizhzhia National University \\ Zhukovskoho str., 66, Zaporizhzhia, Ukraine \\ orcid.org/0000-0003-1368-562X \\ lera.donya228@gmail.com
}

Key words: dictionary article, semanticization, comparative analysis, online game, macroand microstructure of the dictionary.
In the era of globalization, total computerization and informatization, the World Wide Web is becoming an integral part of human life. One of the popular virtual places of communication, in addition to social networks, is online games, which have their own specific words - gaming jargon. Despite the fact that modern humanity spends most of his day on the Internet and online games, especially among young people, are becoming more popular every year, there is not much research on gaming jargon, including lexicographic works on this vocabulary. The study is devoted to an attempt to describe and characterize the structure of the Polish-Russian dictionary of gaming jargon. The article provides a definition of the concept of jargon and highlights the features of the actual gaming jargon, which should be distinguished from computer; describes the structural elements on which the dictionary is created, and lists the units that make up its macroand microstructure. The proposed lexicographic description of gaming jargon in Russian and Polish takes into account the phonetic, graphic, grammatical, wordforming features of each of the languages and a comparative analysis of their differential features. The selected specific features are illustrated by examples that reveal and argue the essence of the statements as much as possible. The dictionary is based on the basic principles of lexicography: the succession of lexicographical works, the significant role of the subjective factor, due to rigid pragmatism, normative in the selection and presentation of lexical material, theoretical and practical diversity of lexicographic works. The results of this study made it possible to compare the system of gaming jargon in Russian and Polish, to identify common and different features, to emphasize the features of each language in the use of lexical units.
Постановка проблеми. Актуальність теми дослідження зумовлена важливістю вивчення геймерского жаргону. Це пов'язано 3 тим, що інтерес до комп'ютерних ігор зростає 3 кожним днем, а лексика, використовувана гравцями, залишається маловивченою. Складання словника цієї соціально обмеженої лексики допоможе новим користувачам, які на початку часто зовсім не розуміють значень слів, що вживаються «просунутими» геймерами. Актуальність нашої роботи зумовлена також екстралінгвістичним факто- ром. Нові гравці завжди хочуть показати себе досвідченими, як би парадоксально це не звучало, навіть якщо грати ще зовсім не навчилися. Їм часто соромно визнати, що вони чогось не знають, інакше більш досвідчені гравці почнуть ставитися до них зневажливо. Тому вивчення геймерского жаргону допоможе новачкам стати більш обізнаними в цьому питанні.

Спроби вивчення геймерскої лексики були зроблені в роботах М.Г. Аханова, А.В. Корольчук [1], П.О. Горшкова [3], однак перші два дослідники 
обмежилися невеликою кількістю слів, описуючи лише їх лексичне значення, а останній не розмежовував комп'ютерний і ігровий жаргон. У цій науковій роботі ми вивчаємо геймерський жаргон, не поєднуючи його з комп'ютерним. На нашу думку, це два різних типи жаргонної лексики.

Метою нашої роботи є опис досвіду складання російсько-польського словника лексем геймерского жаргону на прикладі гри Dota 2. Основними завданнями статті визначені: формулювання дефініції поняття «жаргон», зазначення особливостей геймерського жаргону, опис та характеристика структури запропонованого словника. Об'єктом дослідження $є$ геймерський жаргон гри Dota 2, предметом - лексикографічний опис зазначеної лексики.

Виклад основного матеріалу дослідження. Під геймерським жаргоном ми розуміємо особливий пласт лексичних одиниць, який використовується людьми, що грають у комп’ютерні ігри. Жаргон можна трактувати як певний різновид мови, соціальний діалект, який відрізняється від загальнонаціональної мови особливим лексичним складом, фразеологією тощо. Суттєвою особливістю жаргону $є$ те, що він використовується певними соціальними, професійними чи іншими групами, які об'єднані спільними інтересами (наприклад, військовий або кримінальний жаргон). Деякі лінгвісти, наприклад, В.О. Хомяков, виділяють таку функцію жаргону, як «функція конспіративної комунікації», особливо якщо йдеться про кримінальний жаргон [5, с. 43-44]. Цієї ж точки зору дотримується і О.Д. Швейцер, який вважає, що жаргон - це «зашифрована мова», незрозуміла для необізнаних [7, с. 158]. Подібна точка зору заперечується Л.І. Скворцовим, який відзначає успішне засвоєння багатьох жаргонізмів просторіччям і їх перехід в експресивну базу розмовної мови, що навряд чи було б можливим, володій жаргон таємним характером [4, с. 53-57]. У радянському мовознавстві замість уживаного в зарубіжній лінгвістиці терміну «сленг» широко використовувалася лексема «жаргон» для позначення явищ диференціації мови, які мають вузьку соціальну базу: військовий жаргон, жаргон моряків, студентський, молодіжний, в тому числі й геймерський, який має свої особливості.

Серед особливостей геймерського жаргону ми можемо виділити такі ознаки:

1. Лексеми геймерського жаргону утворюються на базі англійської мови. Це пов'язано 3 тим, що США є одним із лідерів виробництва у світі онлайн-ігор, тому всі нові поняття спочатку виникають англійською. Інші мови зазвичай транслітерують ці слова або просто зберігають англійський корінь, додаючи свої афікси.
2. 3 першого випливає те, що в мовах-реципієнтах лексеми геймерського жаргону зберігають ознаки англіцизмів (транскрипція і транслітерація англійських слів, кореня), оскільки англійська мова світового спілкування, що полегшує гравцям спілкування один з одним незалежно від їх національностей. Це одночасно сприяє поліпшенню знань англійської та дає можливість вільно спілкуватися 3 людьми 3 різних континентів. Отже, за своєю природою геймерський жаргон тяжіє до інтернаціональності.

3. Мета використання зазначеного жаргону полягає в тому, аби швидше висловлювати свої думки, не витрачаючи час на переклад, оскільки в онлайн-іграх потрібна швидка реакція на події. Лексеми мови геймерів короткі, тому сприяють швидкому обміну інформацією.

4. Геймерський жаргон являє собою симбіоз мови-джерела (англійської) і приймаючої мови. Його особливістю $є$ те, що лексема зберігає англійський корінь, до якого приєднуються словотвірні форманти мови-реципієнта. В результаті утворені слова набувають властивостей синтетичної мови.

5. У деяких словах геймерського жаргону лексичне значення може змінюватися. Ці зміни найчастіше полягають у звуженні семантики, оскільки слова можуть вживатися лише в певній ситуації й бути прив'язаними лише до певного випадку.

У сучасній лексикографії можна виділити безліч універсалій, які можуть бути притаманні кожному 3 існуючих типів словників. Будь-який словник складається 3 макроструктури та мікроструктури, які містять у собі певну лексикографічну параметризацію. Це поняття є способом лексикографічної інтерпретації того чи іншого структурного елементу або функціонального явища мови та їх екстралінгвістичних відповідностей. До мікроструктури слід віднести проблеми побудови словникової статті як окремої різнопланової системи всередині складної самостійної системи. Сюди включаються питання формату, обсягу, складу словникової статті, презентації різного роду інформації щодо описуваної мовної одиниці (етимологічні, енциклопедичні, семантичні, граматичні, словотворчі, стилістичні, ілюстративні та інші відомості). Макроструктура складається із загальних принципів структурування лексикографічної праці: синонімічні, антонімічні, омонімічні, паронімічні, гіпо-гіперонімічні (родо-видові) відносини словникових одиниць, зовнішні зв'язки семантичних полів, тематичних i лексико-семантичних груп, принципи розташування мовних одиниць в словнику тощо. У будьякому тлумачному словнику, а також в деяких інших типах словників розрізняються ліва й права частини. Ліва частина словника - це описувані в 
лексикографічній роботі заголовні одиниці. Праву частину складають або семантизація одиниць словника, або сукупність мовних одиниць, які $\epsilon$ перекладними еквівалентами елементів словника.

Для складання словника геймерського жаргону гри Dota 2 нами було проаналізовано й описано 175 лексем російської мови і 174 польської. У другій мові лексем на одну менше у зв'язку 3 лакуною. У російській $є$ слово «катка», прямого еквівалента якому немає в польській мові. Під час відбору матеріалу ми орієнтувалися на частотність вживання й те, наскільки семантика лексем зрозуміла без тлумачення. До слів, значення яких можливо визначити без додаткових відомостей, можна віднести деякі імена персонажів, назви здібностей, предметів, якщо використовується транскрипція / транслітерація для їх передачі. Наприклад, слово «манта» походить від першої частини назви предмета "manta style". Як можна помітити, визначити, що таке манта, можна, просто глянувши на назву предмета, без тлумачення. Тоді як розуміння дісслова «тпинуться» може викликати труднощі. Як зазначено в нашому словнику, в російській мові це слово утворено від абревіатури предмета $m n$ за допомогою суфіксально-постфіксального способу й означає 'переміщення по карті за допомогою сувою телепортаціï'.

Слова розташовані в алфавітному порядку 3 опорою на кирилицю. Макроструктура словника складається з лівої й правої частин. У лівій зазначений словник, тобто сукупність заголовків одиниць російською та польською мовами. 3 точки зору частиномовної приналежності найбільшу кількість складають іменники (82). У словнику також присутня чимала кількість дієслів (32) і кілька прийменників (2). У правій частині розташовано тлумачення слів, характеристика яких буде описана нижче. Крім тлумачення, в деяких випадках наводяться приклади синонімів. Наприклад, харда (hardline) і оффлейн (offline) - поняття, які називають важку лінію в грі, на якій складно добувати золото й досвід. Також у правій частині словника зазначається наявність полісемії та омонімії. Прикладом омонімії може служити лексема «бот» ("bot"), що означає: «1. Назва нижньой лінії на карті. Утворене від англійського bottom низ. 2. Назва персонажів, якими керує комп 'ютер. Створено иляхом транслітерації англійського bot». Ілюстрацією полісеміі може бути слово "реген» ("regeneracja”), яке: «1. Називає сам процес відновлення здоров'я. 2. Називає руну, що дає регенераиію».

Мікроструктура словника представлена у вигляді словникових статей, які містять заголовні одиниці, їх фонетичні, граматичні характеристики, семантизацію, етимологію, деривацію та відсилання. Для фонетичної характеристики заголовних одиниць використовується наголос у російській мові. У польській він не вказується, оскільки, як і в літературній мові, $є$ фіксованим падає на передостанній склад. Граматична характеристика представлена в правій стороні словника, де зазначається частина мови лексеми та відповідні граматичні категорії (наприклад, вид у дієслів, рід у іменників). Обов'язково акцентувалася увага на розбіжності в категорії роду двох мов, якщо вона присутня (наприклад, Ку'рuца Courier - іменник (ж.p. в російській, ч.р. в польській)). Слова в лівій стороні наведені, як і в усіх словниках, у початковій формі: інфінітив дієслова, називний відмінок, однина іменника. Семантизація слів представлена по-різному. Найчастіше це використання тлумачення слова. До деяких слів додається перекладацький еквівалент 3 англійської (наприклад, отвод - pull, замес - highlight). $\mathrm{y}$ правій стороні також вказувалася етимологія слів. У деяких словах зазначалося походження слова не лише в жаргоні, а й в англійській мові. Наприклад, понё'p pumb - znerfić - дієслово доконаного виду, що означає поліпшення героя після оновлення. Спочатку словом nerf називався бренд іграшок, що створений Parker Brothers і в даний час належить Hasbro. Не існує теорії, чому саме це слово перейшло до геймерського жаргону. Можна припустити, що ця компанія розробляла іграшкову зброю, відповідно, це покращувало процес гри деяким дітям, оскільки, чим новіше зброя була, тим крутіше. Так само і в геймерському жаргоні, понерфить означає додати персонажеві поліпшені можливості й характеристики, завдяки чому він стає сильнішим. Іншими словами, на нашу думку, сталося асоціативне перенесення. Способи деривації і шляхи передачі лексем у словникових статтях також враховувалися. У деяких словах вказувалося звуження семантики, якщо таке явище було притаманне цьому слову. Наприклад, $\phi u^{\prime} d u m b-f e e d z i c ́$ - дієслово недоконаного виду, що означає 'часто гинути від руки одного й того ж ворожого персонажа (в основному навмисне)'. Утворений від дієслова to feed, що в перекладі означає «годувати». У семантиці цього слова відбувається звуження, і лексема застосовується в значенні 'згодовувати себе ворогові'. Серед лексикографічних відсилань в словнику є скорочення - см. Воно використовується в тому разі, коли під час тлумачення того чи іншого слова використовується геймерський жаргон. Наприклад, бара'к-barrack - іменник (ч. р.), який називає один 3 типів споруди у грі. Вони знаходяться близько Трону (см. ниже). Якщо зламати ворожі бараки, то по лінії почнуть йти посилені союзні крипьи (см. ниже).

Висновки. Таким чином, результатом нашого дослідження став словник геймерського жаргону, 
який укладався на підставі наявних лексикографічних принципів з урахуванням граматичних та словотворчих відмінностей відповідних лексем у польській і російській мовах. Російській мові властиво використовувати транслітерацію для передачі слів, польська - навпаки, тяжіє до збереження англіцизмів у своєму жаргоні, асимілюючи їх тільки граматично. На нашу думку, це пов'язано $з$ тим, що абетка польської та англійської мов базується на латиниці, тому зручніше для передачі слів користуватися транскрипцією. Перспективою подальших наукових розвідок щодо лексикографічного опису геймерського жаргону гри dota 2 вважаємо створення багатомовних словників цієї лексики, що, з одного баку, сприятиме інтернаціоналізації гри, а 3 іншого, на підставі компаративного співставлення лексичних одиниць надасть можливість визначити своєрідність і специфічність кожної мови щодо асимілюючого освоєння ігрової іншомовної лексики.

\section{ЛІТЕРАТУРА}

1. Аханова М.Г., Корольчук А.В. Игровой сленг как новая форма коммуникации. Актуальные направления научных исследований: от теории к практике. Таганрог, 2016. Т. 2, № 2. C. 81-85.

2. Виноградов В.В. Исследования по русской грамматике: монография. Москва : Наука, $1975.559 \mathrm{c}$.

3. Горшков П.А. Сленг хакеров и геймеров в интернете (рус.): дисс... к-та филол. наук: 10.02.02 / Институт лингвистики и межкультурной коммуникации (МГОУ). Москва, 2006. 68 c.

4. Литературная норма и просторечия / отв. ред. Л.И. Скворцов. Москва : Наука, 1977. 254 с.

5. Хомяков В.О. Введение в изучение слэнга основного компонента английского просторечия: монография. Вологда : Вологодский гос. пед. ин-т, 1971. 104 с.

6. Хомяков В.А. Нестандартная лексика в структуре английского языка национального периода : автореф. дисс. ... докт. филол. наук : 10.02.02. Л., 1980. 49 с.

7. Швейцер А.Д. Очерк современного английского языка в США: монография. Москва : Высшая школа, 1963. 216 с.

\section{REFERENCES}

1. Akhanova M.G., Korol'chuk A.V. (2016). Igrovoy sleng kak novaya forma kommunikatsii. Aktualnyie napravleniya nauchnyih issledovaniy: ot teorii $k$ praktike [Game slang as a new form of communication. Actual directions of scientific research: from theory to practice]. Tahanroh. Vol. 2, № 2. Pp. 81-85.

2. Vynohradov V.V. (1975). Issledovaniya po russkoy grammatike: monografiya [Studies in Russian grammar: monograph]. Moscow : Nauka. 559 pp.

3. Horshkov P.A. (2006). Sleng hakerov $i$ geymerov $v$ internete (rus.): dys. ... [Slang for hackers and gamers on the Internet (Russian): dissertation]. k-ta filol. nauk: 10.02.02 / Instytut linhvistyky ta mizhkul'turnoyi komunikatsiyi (MHOU). Moscow. 68 pp.

4. Literaturnaya norma $i$ prostorechiya [Literary norm and vernacular] / otv. red. L.I. Skvortsov. (1977). Moscow : Nauka. 254 pp.

5. Khomyakov V.A. (1971). Vvedenie v izuchenie slenga - osnovnogo komponenta angliyskogo prostorechiya: monografiya [Introduction to the study of slang - the main component of the English vernacular: a monograph]. Volohda : Volohods'kyy der. ped. in-t. 104 pp.

6. Khomyakov V.A. (1980). Nestandartnaya leksika $v$ strukture angliyskogo yazyika natsionalnogo perioda [Non-standard vocabulary in the structure of the English language of the national period]: avtoref. dys. ... dokt. filol. nauk: 10.02.02. L. 49 pp.

7. Shveytser A.D. (1963) Ocherk sovremennogo angliyskogo yazyika $v$ SShA: monografiya [Essay on Modern English in the United States: monograph]. Moscow : Vyshchaya shkola. 216 pp. 